\title{
Capabilities, difficulties and obstacles for 'energy recovery from MSW' as a sustainable option for waste management in Iran
}

\author{
E. Rahimi \\ Physics Department, Sharif University of Technology, Iran
}

\begin{abstract}
Increasing concerns about unbridled fossil fuel consumption and a growing generation of municipal solid waste (MSW) in Iran and related environmental challenges require adoption of more sustainable approaches in energy and waste management. Energy recovery from waste can play an important role to achieve environmentally sustainable development that has been defined for the country as a main policy. Iran's growing urban population generates massive amounts of MSW that mostly end up in landfills. A population of 75 million is generating 50,000 tonnes of MSW every day that mostly are buried in landfills. Detrimental emissions from landfills and many other long-lasting environmental issues have caused ever-increasing concerns about the current trend of MSW generation and methods of treatment. Despite comprehensive MSW collection, the rate of MSW separation at source and energy or material recovery has remained significantly low. This study aims to investigate capabilities, difficulties and obstacles of energy generation from MSW in a developing country, Iran. It also discusses the reasons for the low motivation to produce energy from MSW and the most suitable method of energy generation from MSW considering current MSW characteristics and the country's climate.
\end{abstract}

Keywords: energy generation, municipal solid waste, landfill, sustainable energy.

\section{Introduction}

The growing stream of Municipal solid waste (MSW) as an inevitable consequence of increasing urbanization has overburdened effective capacity of landfills in most countries. Finding and constructing new sites to dump MSW is not only difficult and expensive due to land limits, environmental regulations, and citizen oppositions living in the vicinity of landfills, but also unsustainable by its 
detrimental impacts on environment. Organic fractions of waste in landfills decompose to produce methane $\left(\mathrm{CH}_{4}\right)$, carbon dioxide $\left(\mathrm{CO}_{2}\right)$, and trace amounts of other toxic substances [1]. The amount of gases generated in landfills depends on the quantity and moisture content of the waste and the design and management practices at the site [2]. $\mathrm{CH}_{4}$ and $\mathrm{CO}_{2}$ are greenhouse gases (GHGs) that contribute considerably to global warming, particularly $\mathrm{CH}_{4}$, a very strong GHG nearly 25 times more potent than $\mathrm{CO}_{2}$ [3]. In 2000, MSW landfills have been responsible for $13 \%$ of global anthropogenic $\mathrm{CH}_{4}$ budget by source [4]. Increasing concerns for the environment have highlighted the harmful impacts of GHGs coming from landfills. Based on waste hierarchy, energy recovery can be an environmentally sound strategy for management of waste that would otherwise go to landfill and create landfill emissions [5]. It can also be a solution to increase energy security [6]. The current paper examines the sustainability of energy generation from MSW in a developing country, Iran. The main aim of this paper is to determine capabilities, difficulties and obstacles of energy generation from MSW in the country. To achieve this aim, quantity of MSW, composition, level of collection and current practices of waste treatment have been studied. Also, reasons of low energy production from renewable resources including waste and sustainability of energy generation from MSW have been discussed.

\section{MSW quantity}

Iran is a developing country with an increasing urbanization trend. In 2011, rate of urbanization in Iran has been $69.1 \%$ [7] being much higher than the world' average level (51\%) [8]. Although urbanization itself is not a problem, lack of efficient approaches to face with its consequences such as higher levels of consumption and massive generation of MSW can result in many difficulties and challenges. The daily quantity of MSW generated in Iran has been estimated at 50,000 tonnes in 2012 [9], and the average per capita generation of MSW has been $670 \mathrm{~g}$ per day [10]. Quantity and characteristics of Waste mostly depends on population size, life style of city inhabitants, their consumption patterns and income level [11]. Therefore, this amount in more affluent areas and tourist trap provinces such as capital city, Tehran, and north and south coastal provinces shows a higher level, for instance, this figure is at around $920 \mathrm{~g}$ for Tehran [12]. Table 1 shows the MSW quantity in big cities of Iran with a population over 1 million $[12,13]$.

Table 1: Quantity of MSW generated in cities with a population of over 1 million.

\begin{tabular}{|l|c|c|c|c|c|c|c|c|}
\hline City & Karaj & Qom & Shiraz & Isfahan & Tabriz & Ahwaz & Mashhad & Tehran \\
\hline Population & $1,614,626$ & $1,074,036$ & $1,460,665$ & $1,756,126$ & $1,494,988$ & $1,112,021$ & $2,749,374$ & $8,154,051$ \\
\hline $\begin{array}{l}\text { MSW } \\
\text { quantity } \\
\text { (tonne/day) }\end{array}$ & 1300 & 650 & 1050 & 1000 & 1200 & 1200 & 1800 & 7500 \\
\hline
\end{tabular}


More than $90 \%$ of MSW generated in Iran is collected through municipal waste management systems. The frequency of Waste collection varies depending on city size and population, but it occurs in most cities once a day. In populous regions such as Tehran, municipal solid wastes are collected twice or even three times a day [9]; however, the rate of MSW segregation at source has remained significantly low at around 7\% [14]. In addition, the level of waste recycling does not exceed $6 \%[15]$.

\section{MSW characteristics}

A main characteristic of MSW in Iran is its high moisture content at around $40 \%$ [16]. It contains a considerable amount of wet and organic materials at about $72 \%$ [16]. MSW is a heterogeneous material and its physical composition depends on socio-economic level, climate conditions and people and/or communities' life style [17-19]. MSW in Iran reflects some discrete compositional characteristics compared to those in developed countries. For instance, food waste, instead of paper, constitutes the largest part of MSW in Iran, so the moisture content of waste is much higher than that in more developed countries. There is higher proportion of organic fraction of MSW in middle and low-income countries, while the highincome countries have larger proportions of paper and plastics in their MSW streams mostly due to higher prevalence of packaging that ends up in the waste stream and increases its amount and volume [20].

There are various climatic conditions and levels of development between urban areas of Iran causing differences in waste quantity and composition. Provinces located in hot and dry areas such as Khuzestan and South East provinces produce less wet waste, and conversely MSW generated in provinces with a humid climate such as Caspian Sea coastal provinces and South west provinces is wetter and contains more organic proportion. Table 2 shows physical analysis of MSW in 10 areas in 2008 [21].

Table 2: Physical analysis of MSW in Iran, 2008.

\begin{tabular}{|c|c|c|c|c|c|c|c|c|c|c|c|}
\hline & 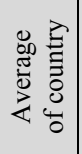 & 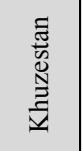 & 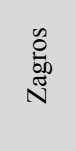 & 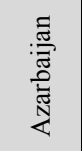 & 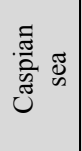 & 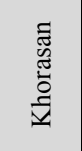 & 点 & 苞 & 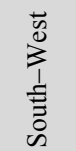 & 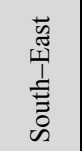 & 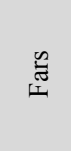 \\
\hline Biodegr & 72.04 & 60.92 & 78.24 & & 77.72 & 70.96 & 76.30 & 74.56 & 78.98 & 62.55 & 64.14 \\
\hline Card & 6.43 & 8.26 & 7.21 & 8.67 & 8.43 & 6.93 & 4.38 & 5.04 & 4.94 & 8.30 & 6.35 \\
\hline Plastic & 7.77 & 8.38 & 7.28 & 1.85 & 7.61 & 6.87 & 5.26 & 6.25 & 7.41 & 12.15 & 12.96 \\
\hline Metal & 2.52 & 4.42 & 1.71 & 2.25 & 0.89 & 2.36 & 2.90 & 2.48 & 2.40 & 3.05 & 2.27 \\
\hline Rubber & 1.14 & 3.24 & 0.52 & 0.00 & 0.47 & 0.74 & 0.97 & 1.11 & 0.40 & 1.90 & 1.32 \\
\hline Textile & 2.86 & 4.06 & 1.4 & 2.87 & 1.24 & 2.93 & 3.72 & 3.29 & 1.62 & 2.25 & 2.00 \\
\hline Glass & 2.03 & 4.11 & 1.94 & 1.81 & 0.91 & 2.27 & 1.71 & 2.03 & 1.89 & 2.25 & 3.23 \\
\hline Wood & 1.10 & 1.1 & 0.6 & 2.39 & 0.96 & 0.00 & 0.00 & 1.82 & 0.00 & .90 & 0.00 \\
\hline Miscellaneous & 4.11 & 5.50 & 1.1 & 2.82 & 1.77 & 6.94 & 4.76 & 3.42 & 2.36 & 6.65 & 7.73 \\
\hline
\end{tabular}




\section{Landfilling as the main option}

In Iran, the predominant option of waste treatment has been, and still is, waste disposal in landfills. Around $84 \%$ of MSW ends up in landfills; however, landfilling is the least sustainable method of waste management according to the waste hierarchy of which only $25 \%$ are buried in engineered landfill sites and the rest are dumped in uncontrolled spaces [22]. Table 3 indicates proportion of different waste treatment options [21].

Table 3: Proportion of different waste treatment options in Iran

\begin{tabular}{|l|c|}
\hline waste management methods & Percentage \\
\hline Landfilling & 84 \\
\hline Composting & 10 \\
\hline Recycling & 6 \\
\hline Energy recovery & 0 \\
\hline Total & 100 \\
\hline
\end{tabular}

\section{Potential of energy generation from MSW}

MSW in low and middle-income countries contains a larger organic content, which means a dense waste with a high moisture content and low heating value [23]. According to Table 2, average percentage of organic fraction of MSW in Iran is estimated $72.04 \%$. This significant proportion of organic wastes makes material recovery and energy generation through burning the MSW unjustifiable and difficult; however, it indicates capability for producing biogas through Anaerobic Digestion (AD) process or for being composted. Also, 4.11\% of MSW generated in the country has no value for either material or energy recovery and should be disposed in landfills.

Table 4 displays the proportion of wet and dry waste in MSW generated in the country in 2008 [21].

Table 4: Wet and dry waste proportion in Iran MSW, 2008.

\begin{tabular}{|l|c|}
\hline Organic wet waste (Digestible and Compostable) & $72.04 \%$ \\
\hline Dry waste (recyclable) & $18.75 \%$ \\
\hline Dry waste (combustible) & $5.1 \%$ \\
\hline Others (landfillable) & $4.11 \%$ \\
\hline
\end{tabular}


Considering MSW composition, the calorific value of MSW in Iran in comparison to developed countries $(8,400-17,000 \mathrm{~kJ} / \mathrm{kg}$ ) [19] is low. The average heat value of MSW in the country is estimated at around $8.46 \mathrm{MJ} / \mathrm{kg}$ [22]. In Sistan and Baloochestan, a very hot and arid province having the least amount of wet material in its MSW, the calorific value of MSW is $8,900 \mathrm{~kJ} / \mathrm{kg}$ indicating the largest value in the country [24].

\section{Energy generation from waste in Iran}

In 2007, the share of energy generation from Iran's MSW has been zero [21]. Two landfill gas plants (LFG) built in Shiraz and Mashhad in 2009 are now operating in country. There is no MSW incineration power plant in Iran, however there is a potential to produce $320 \mathrm{MW}$ power generation from MSW incineration $(25 \%$ efficiency) [25]. Also, there are no AD plants for energy generation from MSW; only a few small scale $\mathrm{AD}$ facilities in rural regions using animal manure [26].Other waste-based energy generation methods such as gasification and pyrolysis have not yet been used as ways of MSW treatment and energy generation.

At the present time, two landfill gas plants are operating in Iran. The first one, built in Mashhad, the second largest city in Iran, and the second one, built in Shiraz. These cities are very important tourist resorts that generate larger amounts of MSW than the average of the country. Mashhad biogas plant is the first LFG plant in the Middle east, with a maximum power output of $600 \mathrm{kWh}$, while the Shiraz biogas facility, the next to be built, is now one of the largest LFG plant in the Middle east with power output of $1065 \mathrm{kWh}$ [27]. The compositional analysis of MSW generated in these cities shows closeness to the average composition of MSW in country. Table 5 displays the Physical analysis of MSW in Shiraz and Mashhad.

Table 5: Physical analysis of MSW in Shiraz [28] and Mashhad [29].

\begin{tabular}{|l|l|c|}
\hline MSW Composition & Shiraz & Mashhad \\
\hline Organic waste & $70.42 \%$ & $64 \%$ \\
\hline Paper and cardboard & $9.34 \%$ & $14.4 \%$ \\
\hline Plastic & $13.7 \%$ & $4.2 \%$ \\
\hline Glass & $1.1 \%$ & $2.8 \%$ \\
\hline Metal & $1.12 \%$ & $1.1 \%$ \\
\hline Miscellaneous & $3.95 \%$ & $13.5 \%$ \\
\hline
\end{tabular}

Since the cost of energy generation from renewable sources is expensive; therefore, in order to encourage private investors to invest in this section, government has guaranteed to buy $1 \mathrm{MWh}$ electricity generated from renewable resources as 4,442,000 Rials equal to $180 \$$ (1 UD $\$ \sim 24,700$ Rial, 2013) [30]. It 
is about 3 times more than the price of buying electricity from fossil fuel plants [31]. Consequently, government pays significant subsidies to make energy generation from renewable resources profitable and attractive. According to financial studies for Shiraz LFG plant, the average cost of $1 \mathrm{kWh}$ electricity in Shiraz LFG plant was estimated $0.03 \$$ (at the time of studies) [28]. Therefore, considering Shiraz LFG plant's financial analysis and subsidies paid by government, generation of electricity from LFG plants seems financially feasible.

\section{Reasons for low energy generation from waste}

Comprising a land area of $1,648,195 \mathrm{~km}^{2}$, Iran is the $18^{\text {th }}$-largest country in the world. Considering the ratio of population to land, and size of non- agricultural areas and deserts (30\% of total land), Iran has plenty of land and void spaces required for burial of waste. Therefore, this abundance of land has caused weak motivations to move from landfilling towards more sustainable options.

Moreover, there is no landfill tax in Iran. Landfill tax is an efficient instrument to reduce the quantity of waste going to landfill and to encourage development of alternative methods of waste treatment [32]. But in Iran waste producers do not bear any cost of waste management. So they do not need to reduce their waste as it is easy and cheap to dispose their waste in landfills. Landfill tax is used by most developed countries because of its proven advantages. The purpose of landfill tax is firstly "to ensure that landfill waste disposal is properly priced so as to reflect its environmental cost" and secondly "to promote a more sustainable approach to waste management in which less waste is produced and more waste is either reused or has value recovered from it" [33].

Another important reason for very low energy generation from waste in Iran is lack of gate fee system, as the gate fees and the sale of energy (electricity and heat) are the main sources of revenue; however the gate fee often generates more revenue. The gate fee offsets the operation, maintenance, labor costs and capital costs of the waste treatment facilities. In the UK, about $70-80 \%$ of revenue of incineration power plants is from the gate fee and the rest comes from the sale of energy (electricity or/and heat) [34]. Table 6 shows the UK gate fees for different waste management options.

Moreover, in recent decades Iran has experienced strict sanctions that targeted its economy and affected all aspects of the people's lives and inflicted massive damages on the country's environment. The harmful impacts of sanctions on the country's industry have restricted Iran's ability to achieve more environmentalfriendly technologies to improve waste management. In fact, sanctions against Iran have brought the process of moving towards waste treatment more sustainable industries to a halt.

Iran is a rich country in terms of having natural resources such as mines, forests, and oil and gas reserves. The country possesses the world's third-largest proven oil reserves and the world's second-largest natural gas resources [36]. Massive fossil fuel resources have caused high dependency on oil and natural gas to meet country's energy demand and low motivation to invest on renewable energy sector. 
Table 6: Level of gate fee for different waste management options in the UK [35].

\begin{tabular}{|l|l|c|}
\hline Treatment & Grade/material/type of facility & Median \\
\hline $\begin{array}{l}\text { MRF } \\
\text { (Material Recovery } \\
\text { Facilities) }\end{array}$ & All & $£ 9$ \\
\hline \multirow{2}{*}{ Organics } & Open-air windrow (OAW) & $£ 24$ \\
& In-vessel (IV) & $£ 46$ \\
& Anaerobic Digestion(AD) & $£ 41$ \\
\hline \multirow{2}{*}{ Landfill } & Non-hazardous Gate fee only & $£ 21$ \\
& Non-hazardous Gate fee plus landfill tax & $£ 93$ \\
\hline Incineration & Pre-2000 facilities & $£ 58$ \\
& Post-2000 facilities & $£ 90$ \\
\hline MBT & & $£ 76$ \\
(Mechanical Biological & & \\
\hline
\end{tabular}

\section{Discussion}

Iran generates a very large amount of waste materials that are mainly discarded in landfills without energy or material recovery. However more than $90 \%$ of MSW generated is collected through municipal waste management systems but the rate of either material or energy recovery is very insignificant because the level of waste separation at source is extremely low. Also, the amount of biodegradable materials such as food waste is considerable thus the moisture content of MSW is high. The high level of biodegradable materials in the waste makes it suitable to generate large volume of biogas through anaerobic digestion (AD) process. AD needs high moisture content for better decomposition of organic fraction of waste. The high average temperature of Iran is another intensifying factor for AD process. Therefore, energy generation from waste through AD technology can be an efficient option. Also, diverting biodegradable waste from landfill prevents the methane and carbon dioxide emissions as the most potent greenhouse gases contributing to global warming and climate change. But, the costs of establishing $\mathrm{AD}$ facilities are relatively high. The key factor that can make a waste-based energy generation technology economically viable is gate fee. Also, landfill tax is another factor that can divert waste from being buried in landfill sites to other waste treatment facilities. In Iran, there are not landfill tax and gate fee; and waste producers do not have any incentive to consider other options of waste treatment rather than landfilling. Therefore; energy generation through AD using MSW as feedstock is not economically viable however Iran's waste characteristics and climate conditions is suitable for anaerobic digestion.

The high moisture content of MSW makes it unsuitable for burning in energy from waste (EFW) plants. The calorific value of MSW in Iran is low because of low level of waste separation at source so combustion of waste cannot produce sufficient heat to generate electricity. In addition, lack of gate fee as the main source of revenue for plant is another obstacle to develop EFW plants. Landfill gas plant seems the only economic option to generate energy from waste in Iran. The availability of waste in the landfills and low level of investment costs are the 
key reason for this claim. Lack of landfill tax has made landfilling the predominant method of waste disposal so there is high available waste in the landfills. Also, massive amounts of biodegradable substances in the waste increase the volume of biogas generated in landfill. Therefore, energy generation from landfill gas is not only a way to reduce the detrimental landfill emissions $\left(\mathrm{CH}_{4}\right.$ and $\left.\mathrm{CO}_{2}\right)$ but also an alternative for fossil fuels consumption. The government to encourage energy generation from renewable sources has guaranteed purchasing the electricity generated from such resources. This government support makes the power generation from LFG economically interesting for private investors to invest for establishing LFG plants.

Iran has a high dependency on fossil fuel to meet its energy need. Fossil fuels consumption is the principal cause of $\mathrm{CO} 2$ emission as Iran has the $10^{\text {th }}$ place of carbon dioxide emission in the world [37]. Therefore, there is a real need to find alternative energy resources. MSW generated in Iran has high potential for this purpose if the existing obstacles are removed. First, the level of waste separation at source should be increased. The cost of labour is very low; therefore, it can be achieved through establishing manual waste separation plants supported by municipalities. Second, there is a need to levy landfill tax and determine gate fee. However, it may increase the risk of illegal landfilling in uncontrolled sites.

\section{Conclusion}

Considering daily quantity of 50,000 tonnes for MSW generation, Iran needs to use more sustainable methods of waste management to avoid related environmental issues. Landfilling as the most prevalent approach has induced many long-lasting risks and damages to Iran's environment. Growing rate of urbanization and its consequences such as increasing generation of MSW and energy demand make energy recovery from MSW an important option. Iran has a high capability of power generation from its MSW that current situation shows a significant neglected capacity. Considering high moisture content of MSW and average temperature of the country, generation of biogas through an AD process is the most suitable method. However, lack of landfill tax keeps landfilling the cheapest and easiest way of getting rid of waste for waste producers. Also, in the absence of gate fee investors have low financial motivation to establish AD plants and other waste-based facilities. Therefore, levying landfill tax and putting gate fee are of the first essential steps to make energy generation from MSW feasible. Moreover, this fact that despite the very regular and comprehensive municipal garbage collection services, separation at source is at a low level causes many difficulties for energy generation. Consequently, moving towards more MSW separation at source is a key factor for sustainable waste management system including more energy and material recovery leading to an environment protection and natural resource conservation.

\section{References}

[1] Park J., Shin H. Surface emission of landfill gas from solid waste landfill. Atmospheric Environment 2001; 35: 3445-3451 
[2] Kothari R., Tyagi V., Pathak A. Waste-to-energy: A way from renewable energy sources to sustainable development. Renewable and Sustainable Energy Reviews 2010; 14: 3164-3170

[3] He C., Herman D., Minet R., Tsotsis T. A catalytic/sorption hybrid process for landfill gas cleanup. Industrial and Engineering Chemistry Research 1997; 36: 4100-4107

[4] EPA compilation, 2002. Methane Emissions from Landfills. Available at: www.epa.gov/Imop/documents/pdfs/conf/10th/weitz.pdf

[5] Beylot A., Villeneuve J., Bellenfant G. Life Cycle Assessment of Landfill Biogas Management: Sensitivity to diffuse and combustion air emissions. Waste management 2013; 33: 401-411

[6] Whalen S. C., Reeburgh W. S., Sandbeck K. A. Rapid methane oxidation in a landfill cover soil. Applied Environmental Microbiology 1990; 56: 3405-3411

[7] Central Intelligence Agency, The World Factbook. Available at: https://www.cia.gov/library/publications/the-world-factbook/fields/2212. html [accessed December 2013]

[8] United Nations (UN), Economic \& Social Affairs, World Urbanization Prospects 2011. Available at: www.esa.un.org/unup/pdf/WUP2011_ Highlights.pdf

[9] Association of Iranian Recycling Industries (AIRI), 2010. Available at: http://www.airi.ir

[10] Farzadkia M., Jorofi S., Ravanipoor M. Investigation of waste management plan of Tehran. 12 $2^{\text {th }}$ National Conference of Environment Health, 2009

[11] Troschinetz A. M., Mihelcic J. R. Sustainable recycling of municipal solid waste in developing countries. Waste management 2009; 29: 915-923

[12] Shiraz Municipality, Waste Management Organization, MSW Quantity of big cities, 2012. Available at: http://www.eshiraz.ir/bazyaft/fa/tonaj,5555

[13] Statistical Centre of Iran (SCI), 2013. Available at: ttp://www.amar.org.ir/Default.aspx?tabid=133

[14] Iran Department of Environment (DoE), 2010. Available at: http://www.moe.org.ir

[15] Association of Iranian Recycling Industries (AIRI), 2011. Available at: http://www.airi.ir/

[16] Abdoli M., Karbasi A., Ghaznavi kashani M. Waste recycling - Case study: Tehran. 12 ${ }^{\text {th }}$ National Conference of Environment Health 2009

[17] Abu Qdais H., Hamoda M. F., Newham J. Analysis of residential solid waste at generation sites. Waste Manage 1997; 15: 395-406

[18] Cheng H., Hu Y. Municipal solid waste (MSW) as a renewable source of energy: Current and future practices in China. Bioresource Technology 2010; 101: 3816-3824

[19] Patumsawad S., Cliff K. R. Experimental study on fluidised bed combustion of high moisture solid waste. Energy conversion and Management 2002; 43: 2329-2340

[20] United Nations (UN), United Nations Environment programme, 2011, Waste Investing in energy and resource efficiency, Available from: 
www.unep.org/greeneconomy/Portals/88/documents/ger/GER_8_Waste.p df

[21] Hasanvand M., Nabizadeh R., Heidari M. Analysis of municipal solid waste in Iran. National conference of Health and Environment 2008

[22] Takdastan A. Feasibility study of using landfill bioreactor in order to energy, material and fertilizer recovery. 3rd National conference of Environment and sustainable development 2010

[23] Daskalopoulos E., Badr O., Probert S. An integrated approach to municipal solid waste Management. Resources, Conservation and Recycling 1998; 24: 33-50

[24] Nejat P., Morsoni A., Jomehzadeh F., Behzad H., Vesali M., Msjid M. Iran's achievements in renewable energy during fourth development program in comparison with global trend. Renewable and Sustainable Energy Review 2013; 22: 561-570

[25] SUNA, Renewable Energy Organization of Iran, Available at: http://www.suna.org.ir [2009]

[26] Dehghani A., Dehghani M., Azam K., Asgari A., Baneshi M. Quantitative and qualitative potential of MSW in Tehran. Iranian Journal of Public Health 2009

[27] SUNA, Renewable Energy Organization of Iran, Available at: $\mathrm{http}: / / w w w . s u n a . o r g . i r[2011]$

[28] Adl M., Goodarzi rad R., Booghlandashti B., Bozorgmehri Sh., Lari H. Results of feasibility study of electricity generation from landfill gas in Shiraz. $20^{\text {th }}$ International power system conference 2005

[29] Mashhad Municipality, 2005

[30] SUNA, Renewable Energy Organization of Iran, Available at: http://www.suna.org.ir [2013]

[31] Ministry of Energy, Available at: http://www.moe.gov.ir [2013]

[32] Morris J., Read A. The UK landfill tax and the landfill tax credit scheme: operational weaknesses. Resource, Conservation and Recycling 2001; 32: 375-387

[33] Morris J., Phillips P., Read A. The UK landfill tax: an analysis of its contribution to sustainable waste management. Resource, Conservation and Recycling 1998; 23: 259-270

[34] Jamasb T., Nepal R. Issues and options in waste management: A social costbenefit analysis of waste-to-energy in the UK. Resources, Conservation and Recycling 2010; 54:1341-1352

[35] WRAP Gate fees Report, Comparing the cost of alternative waste treatment options, 2013

[36] Oil and Gas Journal, Iran, Energy production and consumption. January 2010. Available at: http://www.ogj.com

[37] Banan Z., Maleki A. Carbon Capture \& Storage Deployment in Iran. Energy Procedia 2013; 37: 7492-7501 